\title{
Impact of salt reduction on the number of microorganisms and a sensory analysis for Kranjska sausages during their shelf-life
}

\author{
Livija TUŠAR ${ }^{1,2^{*}}$, Irena Leonida KROPF ${ }^{3}$, Avrelija CENCIČ ${ }^{4}$ \\ ${ }^{1}$ Jožef Stefan Institute, Jamova cesta 39, 1000 Ljubljana, Slovenia \\ ${ }^{2}$ Centre of excellence for integrated approaches in chemistry and biology of proteins, Jamova cesta 39, 1000 Ljubljana, Slovenia \\ ${ }^{3}$ Inštitut KON-CERT Maribor, Vinarska ulica 14, 2000 Maribor, Slovenia \\ ${ }^{4}$ University of Maribor, Faculty for Agriculture and Life Sciences, Pivola 10, 2311 Hoče, Slovenia \\ Avrelija Cencič passed away on 14.12.2012.
}

\begin{abstract}
Salt is an important ingredient in the production of meat product. Any reduction of salt requires a special treatment. This study was conducted to evaluate the effect of salt reduction on the growth of microorganisms in Kranjska sausages during their shell-life and to carry out a sensory assessment. The 18 lots of sausages were prepared under salt-reduced $(1.6 \%)$ and control (2.3\%) salt concentrations, directly on the production line. A total of 85 sausages were analysed and the data were used for the comparisons of groups (ANOVA) and to detect the significant variables (polynomial models) influenced on the total number of microorganisms (TNMs). The significant differences were determined between the lots (representing the microbiological status of the stuffing), between the salt-reduced samples and control samples, and between the different humidity levels. The correlations and significant relationships were determined between the TNMs and the lots, the salt concentrations, and the relative humidity. The polynomial models were to general to be used for the prediction. For sensory analysis implemented on $40^{\text {th }}$ day 18 sausages were assessed. The reduction of salt resulted in lower scores in the sensory evaluation. The less-salted sausages contained more microorganisms.
\end{abstract}

Key words: Kranjska sausage, reduction of salt, sensory evaluation, models, relative humidity

\section{INTRODUCTION}

Table salt is one of the oldest food preservatives. It was probably already used in prehistoric times. For decades, the main question has been what is the healthy daily amount of salt in our diet and, in particular, what is its impact on human health? The WHO and FAO recommend $5 \mathrm{~g}$ of salt (or $2 \mathrm{~g}$ of sodium) per person as the maximum daily intake (WHO, 2003). Regarding the WHO recommendations, reformulations to reduce the amount of salt have been made in bread, meat and in some dairy and convenience foods (Kloss et al. 2015).

A large intake of salt has proven to be harmful to human health. Table salt is an important nutritional risk factor for hypertension and a resulting stroke, as well as other cardiovascular diseases (Doyle and Glass 2010). Slovenia is among four countries where the inhabitants have a blood pressure that is too high. Slovenians are also among the European consumers with a very high daily intake of salt. Therefore, Slovenia adopted a National Action Plan to reduce the salt in the diets of people in Slovenia for the period 2010 2020 (Kloss et al. 2015).

Salt is essential for human life, and the meat products are one of the important sources of salt. It influences the texture, the flavour and the colour of meat products, and consequently the microbiological stability and the shelf-life of meat products. 


\section{The impact of salt on texture, flavour and colour}

A salty taste is only detected if the taste receptors react with the salt in the solution (Desmond 2007, Doyle and Glass 2010). In certain food types $\mathrm{NaCl}$ could be replaced by alternative salts and other additives: $\mathrm{KCl}$, a mixture of phosphates and polyphosphates, glycine and potassium lactate, different proteins, nitrates, nitrites, magnesium sulphate, spices, and L-lysine hydrochloride (Desmond 2006). Salt also affects the pigment of the meat. By accelerating the oxidation of myoglobin in meat myoglobin, an undesirable grey colour begins to form in the muscle tissue. With the selection of the appropriate technological procedures (Kilcast 2007) the quantity of the required salt could be reduced. However, the reduction in the amount of salt had a significant impact on the colour and the flavour of the sausage (Aaslyng 2014).

\section{The impact of salt on microbiological stability and shelf-life}

Water in an appropriate form is essential for the growth of microorganisms in meat products. From ancient times, the preservation of food has therefore focused on controlling the moisture in the food. The current hypotheses about binding water in the meat are based on the electrostatic, osmotic and capillary forces, upgrading recently on the waterholding hypothesis: surface force, electric double-layer force, hydrophobic interaction, and repulsive entropic forces. The influence of salt on the ability of minced meat and fat to bind water is very complex and depends on the involved structures of many proteins, i.e., the myosin family, actin, actomyosin, titin and many enzymes and their ability to interact (Puolanne and Halonen 2010, Soladoye et al. 2015).

Salt is also dissolved in the water contained in the meat, and in this way the salt concentration and the osmotic pressure in the meat juice is increased. This increased osmotic pressure inhibits the life processes in bacteria, their growth and reproduction to the point where they can no longer have a detrimental impact on the meat. Part of the free water is bound to salt; therefore, the activity of the water $\left(a_{w}\right)$ is decreased (Desmond 2007, Doyle and Glass 2010).

Salt reduction causes problems with food safety because the microbiological stability of meat products is worsened and the shelf-life is shortened. Before reducing the amount of salt it is necessary to optimize recipes with respect to the replacement of salt with the appropriate equally-acting substances. The most common foodborne pathogens in meat and meat products are bacteria of the genera Salmonella, Campylobacter, Listeria, Escherichia, Staphylococcus, Clostridium, VibrioandBacillus(Desmond 2006, Desmond 2007, Doyle and Glass 2010) and analysis of determination of the types of micro-organisms are necessary (Hwang 2009, Pereira 2011, Giaouris 2014, Sharedeh 2015).

Therefore, the predictions of the growth rates for harmful microorganisms in meat products during their shelf-life have been driven mainly from the point of view of the microbiological safety of the food. Food safety and the development of growth models were initiated by governments, for example, the USDA Pathogen Modelling Program (U.S. Department of Agriculture), Combase (Institute of Food Research from UK, USDA, and Food Safety Center from Australia), and Seafood spoilage and Safety Predictor (Technical University of Denmark) (Doyle and Glass 2010, Hwang 2013). These models are based on real data, such as meat-product recipes (i.e., type of meats, salt, seasonings, nitrite content and more), food-processing characteristics, storage conditions, etc. Growth models were developed for different foodborne pathogens such as Listeria monocytogenes, Salmonella spp., Yersinia unterocolitica, Escherichia coli. Some models are based on only one effect, i.e., the storage temperature or additional effects, i.e., temperature, $\mathrm{pH}, \mathrm{NaCl}$ concentration, activity of the water, modified atmosphere of packed food (Mejlholm et al. 2010).

The aims of this study were to statistically evaluate the impact of salt reduction on the number of microorganisms and on a sensory analysis on the $40^{\text {th }}$ day after production for Kranjska sausages during their shelf-life. A total of 85 sausages were analysed according to the selected experimental design. The variability of the TNM during the shelf-life was expressed with the intra-assay coefficient of variability. The statistical analysis was designed to reveal the differences between two groups of sausages, i.e., the salt-reduced (1.6\% salt concentration) and control samples $(2.3 \%$ salt concentration), by using ANOVA and taking into account the total number of microorganisms, the stuffing (lots), the salt concentrations, and the humidity on the morning of the production day. And secondly, to determine the influence/importance of the stuffing (lot), selected sampling days, salt concentrations, morning humidity on the day of the production, and the influence of the daily production environment on the number of microorganisms on the basis of polynomial models. The sensory analysis was performed on 18 sausages to find out if salt reduction had an influence on the colour, odour and taste of the sausages on the $40^{\text {th }}$ day after production.

\section{MATERIALS AND METHODS}

\section{Production of Kranjska sausages and technological specificities}

Kranjska sausage is a pasteurized, semi-durable sausage made from coarsely minced pork meat category I (percentage of fat up to $10 \%$ ), solid fat, also category I, and selected spices. First, $400 \mathrm{~kg}$ of pork meat was cut in the meat grinder. Then, $150 \mathrm{~kg}$ of this pork was salted with $2.80 \mathrm{~kg}$ of $0.5 \%$ nitrite salt. After 24 hours the stuffing for the sausages was prepared by mixing $150 \mathrm{~kg}$ of pork meat, bacon, selected spices (garlic, pepper), a specific quantity of $0.5 \%$ nitrite salt and a specific amount of coarsely minced pork meat, so that the total weight of the stuffing was $400 \mathrm{~kg}$. A total of $50 \mathrm{~kg}$ of well-homogenized mass was then taken, tagged and filled into a pork intestine with a diameter of $32 \mathrm{~cm}$. The target concentration was from $1.5 \%$ to $1.7 \%$ (Ministry of health 2010). To the remaining amount of stuffing we added a specified amount of salt to reach the target concentration 
of $2.33 \%$ and mixed it well. The stuffing was then filled in thin a pork intestine and closed with a short wooden stick in pairs with coupled ends (Figure 1). The sausages were then smoked hot and pasteurized to the target central temperature of $70^{\circ} \mathrm{C}$. This procedure guarantees that no pathogen microorganism harmful to human health remained in the sausages. The sausages were then cooled to the target core temperature of $6^{\circ} \mathrm{C}$, packed in a controlled atmosphere, and stored at a temperature of $6^{\circ} \mathrm{C}$.

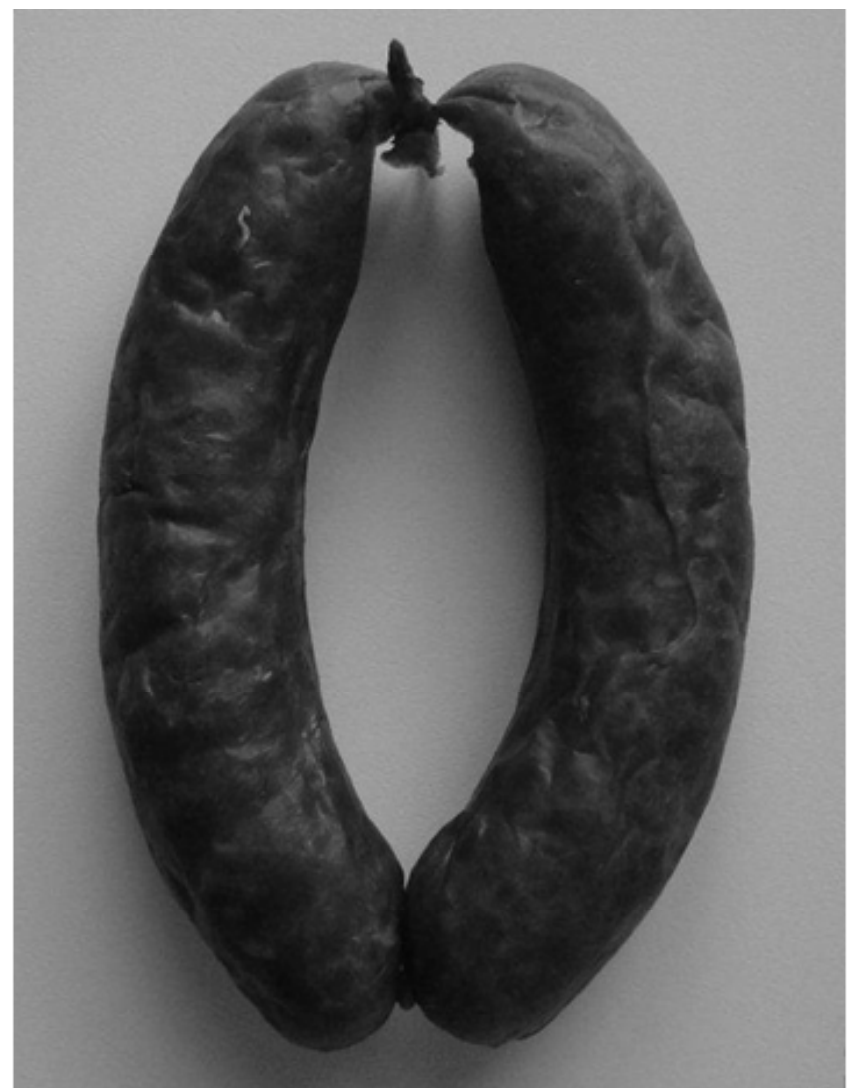

Fig. 1: Kranjska sausage.

The production day for the sausages is expressed as the "lot". For example, lot 11215 means the year 2011, while 215 means the day of the year when the sausage was produced. In this case, the production day was the $3^{\text {rd }}$ of August 2011.

Kranjska sausage is eaten warm, after a brief overheating in hot water to obtain a very specific taste and a high culinary quality. The surface of the sausage is reddish brown (see Figure 1), with a mild odour of smoke; the meat is pinkish red in the cross-section, and the bacon is white and insoluble. The texture is taut, crispy and juicy. The aroma is full and typical for a desalinated, specifically seasoned and smoked pork.

\section{Analytical determination of the $\mathrm{NaCl}$ in the sausages after a thermal and a cooling process}

The actual salt content in Kranjska sausages was analytically determined after the thermal processing at $70^{\circ} \mathrm{C}$ and after the cooling of the product to $6^{\circ} \mathrm{C}$ using the Mohr method. The determination of concentrations of $\mathrm{NaCl}$ is based on the titration of chlorides by $\mathrm{AgNO}_{3}$ (ISO 1841-2:1996).

\section{Determination of the total number of microorganisms (TNMs)}

The analysis was performed according to ISO 4833:2003E. This method is appropriate for a determination of the TNM for aerobic mesophilic bacteria in food and feed, in this case in $20 \mathrm{~g}$ of the sausage, by counting the number of grown colonies on a solid medium after aerobic incubation at $30^{\circ} \mathrm{C}$. Pathogens were not expected due to the thermal and cooling process. Therefore, the species of microorganisms and pathogens were not analysed. The TNMs were counted on days $1,5,10,15,20,25,30,35$ and 40.

We were not able to determine the TNM of the raw pork meat before its chopping in the meat grinder because it consisted of many small meat parts. The first measurement of the TNM was meaningful on the $1^{\text {st }}$ day after the sausage was prepared, heated to $70^{\circ} \mathrm{C}$ and cooled to $6^{\circ} \mathrm{C}$.

\section{Sensory evaluation on the $40^{\text {th }}$ day after production}

The sensory evaluation took place on the $40^{\text {th }}$ day after production. Three trained evaluators performed the sensory evaluation. The evaluators assessed the reduced-salt samples and the samples with the standard salt content.

Before the assessment, the samples of sausages were heated and served on white plates. The evaluators assessed the colour of the sausage cross-section, together with the colour of the exterior of the sausage, the odour and the taste of the sausage. The maximal score was 33 . The sensory assessment criteria are shown in Table 1.

Table 1: Sensory assessment criteria.

\begin{tabular}{|l|l|l|}
\hline $\begin{array}{l}\text { Sensory } \\
\text { assessment } \\
\text { criteria }\end{array}$ & Score & Description \\
\hline Section colour & 3 & $\begin{array}{l}\text { Typical colour, without grey } \\
\text { areas }\end{array}$ \\
\hline Odour & 0 & $\begin{array}{l}\text { Atypical colour of the section } \\
\text { and with expressed grey areas }\end{array}$ \\
\hline Taste & 3 & $\begin{array}{l}\text { Pleasant, typical and } \\
\text { harmonious }\end{array}$ \\
\hline & 5 & $\begin{array}{l}\text { Non-harmonic, atypical } \\
\text { and with the emergence of a } \\
\text { rancidity, sour or musty }\end{array}$ \\
\hline $\begin{array}{l}\text { Pleasant, typical and } \\
\text { harmonious }\end{array}$ \\
\hline
\end{tabular}




\section{Sampling}

The production of sausages was carried out under constant conditions. The technological process enshured the homogeneity of ingredients in the stuffing. No more than one lot was prepared per day.

From $400 \mathrm{~kg}$ of the stuffing (one lot) 1666 sausages are usually prepared. In this case before the final salting, $50 \mathrm{~kg}$ of stuffing were taken for the preparation of 208 less-salted sausages. The rest of the stuffing was additionally salted and 1458 sausages were then prepared with the controlled concentration of the salt. 18 lots were included with the following lots numbers $11215,11216,11217,11220,11221$, $11222,11223,11224,11228,11229,11235,11236,11237$, $11238,11240,11264,11265$, and 11266.

The study was conducting and sampling was implemented according to the selected experimental design in three parts:

1. TNM counting on $40^{\text {th }}$ day after production for 18 lots for two salt concentrations

In this case 36 sausages were randomly taken as samples for the analysis of each lot and for both salt concentrations. The data from the samples were divided into two sets for the statistical analysis because the last three lots were prepared one moth later then the others. Therefore, Set A consisted of the data for 30 samples/sausages for 15 lots: 11215, 11216, $11217,11220,11221,11222,11223,11224,11228,11229$, $11235,11236,11237,11238$, and 11240. Set B consisted of data for 36 samples: set A and lots 11264, 11265, and 11266.

2 . TNM counting on 9 days: $1^{\text {st }}, 5^{\text {th }}, 10^{\text {th }}, 15^{\text {th }}, 20^{\text {th }}, 25^{\text {th }}, 30^{\text {th }}$, $35^{\text {th }}$, and $40^{\text {th }}$ for three lots $11264,11265,11266$ and two salt concentrations.

In this case 54 sausages were randomly picked as the representative for 3 lots, for two salt concentrations and for 9 sampling days. The TNM values on the $40^{\text {th }}$ days of 6 samples for lots 11264, 11265, and 11266 and for two salt concentrations were used also in the first part of the study. One replication of the TNM counting on the $30^{\text {th }}$ day was made for the less-salted sausages. The two salt-reduced sausages on the $30^{\text {th }}$ day were taken from lot 11264 . Set C consisted of analysed data for 55 sausages, also taking into account the replication.

Set D consisted of data for all 85 analysed sausages.

3. Additionally, 18 sausages were randomly selected for lots $11264,11265,11266$ for the implementation of the sensory analysis, i.e., 3 assessors $\mathrm{x} 3$ lots $\mathrm{x} 2$ salt concentrations.

The sausages prepared and used in the present study were in line with the Commission Regulation for the microbiological criteria for meat products (Commission Regulation 2005) and Guidelines for microbiological safety, which are intended for the final consumer (Rupel et al. 2009). This meant that all samples were free of pathogenic microorganisms due to the selected technological procedure.

Table 2: The study variables.

The independent variables

\begin{tabular}{|c|c|c|c|}
\hline Sign & Name & Type of variable & The range or the scale points \\
\hline $\mathrm{X} 1$ & $\begin{array}{l}\text { The stuffing for the } \\
\text { sausages(the lot) }\end{array}$ & Numeric- discrete value & $\begin{array}{l}18 \text { lots with short names and actual numbers in } \\
\text { bracket L1(11215), L2(11216), L3(11217), L4(11220), } \\
\text { L5(11221), L6(11222), L7(11223), L8(11224), } \\
\text { L9(11228), L10(11229), L11(11235), L12(11236), } \\
\text { L13(11237), L14(11238), L15(11240), L16(11264), } \\
\text { L17(11265), L18(11266) }\end{array}$ \\
\hline $\mathrm{X} 2$ & $\begin{array}{l}\text { The sampling days after the } \\
\text { sausages' production }\end{array}$ & Numeric- discrete value & 9 sampling days $1,5,10,15,20,25,30,35,40$ day \\
\hline $\mathrm{X} 3$ & The $\mathrm{NaCl}$ concentration & $\begin{array}{l}\text { Numeric -continuous } \\
\text { value }\end{array}$ & $\begin{array}{l}2 \text { concentrations area - reduced from } 1.43 \% \text { to } 1.65 \% \\
\text { marked as R and control from } 2.09 \% \text { to } 2.50 \% \text { marked } \\
\text { as C }\end{array}$ \\
\hline
\end{tabular}

The independent and confounding variables

\begin{tabular}{|l|l|l|l|}
\hline X4 & $\begin{array}{l}\text { The relative humidity on } \\
\text { the morning on the day of } \\
\text { the production }\end{array}$ & $\begin{array}{l}\text { Numeric- continuous } \\
\text { value }\end{array}$ & $62 \%$ to $88 \%$ \\
\hline X5 & $\begin{array}{l}\text { The day of the week when } \\
\text { production took place }\end{array}$ & Numeric - discrete value & $\begin{array}{l}6 \text { days Monday, Tuesday, Wednesday, Thursday, Friday } \\
\text { and Sunday or } 1,2,3,4,5,7\end{array}$ \\
\hline
\end{tabular}

\section{The dependent variable}

\begin{tabular}{|l|l|l|l|}
\hline Sign & Name & Type of the variable & The measured range \\
\hline Y & $\begin{array}{l}\text { The total number of } \\
\text { microorganisms (TNM) }\end{array}$ & $\begin{array}{l}\text { Numeric - continuous } \\
\text { value }\end{array}$ & $1000-39000$ \\
\hline
\end{tabular}




\section{Statistical analysis}

On the basis of the collected data and analysed values the variables for the statistical analysis were selected. Table 2 shows the selected variables. The independent variables were the lot (X1), the sampling days (X2), the $\mathrm{NaCl}$ concentration (X3), the confounding/independent variables for the relative morning humidity (X4) and the day of the week expressing the daily production conditions (X5) and one dependent variable TNM (Y). X1 represented the impossible-to-define microbiological status of the stuffing for the sausages (small parts of meat from different origins) at the beginning of the production. X4 was the relative humidity in the morning (\%) on the day of the production (ARSO 2011). X4 was recorded as a hidden independent variable. Therefore, the levels were not planned in advance. X5 was recorded as the potential hidden variable, which represented the influence of the daily working environment, i.e., the personnel. The dependent variable TNM (Y) was the total number of microorganisms.

The statistical analysis included:

1. Data visualizations

Scatter plots were used for the visualization of the data from set $\mathrm{B}$ and set $\mathrm{C}$.

2. Tests for normality

The Shapiro-Wilk and Kolmogorov-Smirnov tests were implemented for testing the normality of the data for sets A, $\mathrm{B}, \mathrm{C}$ and $\mathrm{D}$, with the purpose of selecting parametric or nonparametric methods for the statistical analysis.

3. Parametric and non-parametric tests for the comparisons of the salt-reduced and control samples.

For the analysis of set B, Friedman's two-way non-parametric analysis of variance (ANOVA) and the non-parametric Kruskal-Wallis test were used. For the analysis of set $\mathrm{C}$ the analysis of variance for normally distributed data was calculated.

4. Calculation of correlations between two selected variables and expression of the importance of selected independent variables according to a selected dependent variable

The Pearson product-moment and Spearman rank-order correlations were calculated to determine the correlations between the variables. The regression analyses were carried out to confirm the relationships between selected variables and their significance on the basis of statistically significant models (Freund and Littell 1991).

The linear regression was used to test the relationship between the number of microorganisms TNM (as the dependent variable) and the selected independent variables (Table 2). The general equation for the linear polynomial models with the intercept was:

$\log _{10} \mathrm{Y}=$ intercept $+\mathrm{Ai}^{\star} \mathrm{X} 1+\mathrm{Bi}^{\star} \mathrm{X} 2+\mathrm{Ci}^{\star} \mathrm{X} 3+\mathrm{Di}^{\star} \mathrm{X} 4+$ $\mathrm{Ei}^{\star} \mathrm{X} 5$

or without the intercept:

$\log _{10} \mathrm{Y}=\mathrm{Ai}^{\star} \mathrm{X} 1+\mathrm{Bi}^{\star} \mathrm{X} 2+\mathrm{Ci}^{\star} \mathrm{X} 3+\mathrm{Di}^{\star} \mathrm{X} 4+\mathrm{Ei}^{\star} \mathrm{X} 5$

The criteria for the evaluation of the models were: the F and $\mathrm{p}$ values of the model, the Error, the Correlation coefficient, the RMS (\%) and the Shapiro-Wilk and the KolmogorovSmirnov normality tests for checking the normal or nonnormal distributions of the residuals. The equation for RMS(\%) was as follows:
RMS(\%)=SQRT(Error/n)/(Ymax-Ymin $)^{\star} 100$

The "Error" was the square root of the difference between the measured Y and the calculated Y. " $n$ " was the number of samples. Ymax was the maximum value of the measured $Y$ and Ymin was the minimum value.

A variance inflation factor (VIF) and a condition index (C.I.) are tests for detecting the multi-collinearity to exclude possible hidden dependencies between selected independent variables in the polynomial models. The multi-collinearity existed if one variable represented a linear combination of the other variables (Montgomery and Peck 1989, Freund and Littell 1986).

The correct metric with which to analyse the selected variables was not apparent. The Box-Cox power transformation of the dependent variable and the standardization of independent variables were performed to improve the fit of the polynomials to the data (Box-Cox 1964, Winsberg and Ramsay 1980, SAS/Stat 2008). The standard procedure PROC TRANSREG (SAS 9.4) was carried out. The optimal transformation for $Y$ was determined on the basis of changing the $\lambda$ list from -2 to 2 by 0.05 and it was the decimal logarithm $\log _{10} \mathrm{Y}$. For the independent variables the spline transformations (spline is a piecewise polynomial of degree $\mathrm{k}$ with function values and the first $\mathrm{k}-1$ derivatives) with a certain number of knots were the most appropriate. The knots were the number of discontinuous areas within the spline. A larger number of knots increased the fit of the spline function to the data. The starting number of knots in the case of the spline transformations was the number of levels of the independent variables. We increased the number of knots up to 10 to bend the curve more closely to the data.

5. Variability determination

The repeatability and variability of the data were expressed on the basis of one replicated TNM counting and an intraassay coefficient of variation (intra $\mathrm{CV}$ ) for the set $\mathrm{C}$. The intra $\mathrm{CV}$ was also calculated to avoid misleading conclusions on the basis of only one TNM replicated counting.

6. Parametric and non parametric tests for the sensorial analysis

This was obtained on the basis of the parametric and nonparametric tests of the differences between the control and the salt-reduced samples' scores for the odour, the colour of the section, the outside colour, and the taste. The parametric tests (the paired t-test, two-independent samples t-test) and non-parametric tests (Wilcoxon Signed-rank test, WilcoxonMann Whitney test) were calculated. The paired T test or Wilcoxon signed-rank test were used for a comparison with the independent tests because the same stuffing (one lot) was used for the preparation of the salt-reduced sausages and after the addition of the salt also for the control sausages. The normality test Shapiro-Wilk for checking the distributions of the differences between the samples was also employed.

A statistical analysis was calculated with the program SAS 9.4 for Windows.

\section{RESULTS AND DISCUSSION}

The results of the first part of the study, set A,B: detecting of the variables affecting the TNM on the basis of group 
Table 3: The p-values under the null hypothesis of normality of Shapiro-Wilk and Kolmogorov-Smirnov tests are displayed.

\begin{tabular}{|l|l|c|c|c|c|}
\hline & & A set & B set & C set & D set \\
\hline Variable & Test for normality & $p$ Value & $p$ Value & $p$ Value & $p$ Value \\
\hline $\mathrm{Y}$ & Shapiro-Wilk & $<0.0001$ & $<0.0001$ & 0.0003 & $<0.0001$ \\
\hline $\mathrm{Y}$ & Kolmogorov-Smirnov & $<0.0100$ & $<0.0100$ & $<0.0100$ & $<0.0100$ \\
\hline $\log \mathrm{Y}$ & Shapiro-Wilk & 0.0070 & 0.0033 & 0.0493 & 0.0004 \\
\hline $\log \mathrm{Y}$ & Kolmogorov-Smirnov & $<0.0116$ & 0.0114 & $>0.1500$ & 0.0394 \\
\hline
\end{tabular}

Table 4: Friedman's two-way non-parametric analysis of variance (ANOVA) and non-parametric Kruskal-Wallis test are displayed for set $B$.

Friedman's two-way nonparametric analysis of variance

4.A Model

\begin{tabular}{|l|r|c|c|c|c|}
\hline Source & DF & Sum of Squares & Mean Square & F Value & Pr $>$ F \\
\hline Model & 18 & 3667.611111 & 203.756173 & 24.76 & $<.0001$ \\
\hline Error & 17 & 139.888889 & 8.228758 & & \\
\hline Corrected Total & 35 & 3807.500000 & & & \\
\hline
\end{tabular}

\begin{tabular}{|c|c|c|c|}
\hline R-Square & CoeffVar & Root MSE & RlogY Mean \\
\hline 0.963260 & 15.50584 & 2.868581 & 18.50000 \\
\hline
\end{tabular}

4.B Significance of the variables in the model

\begin{tabular}{|l|r|c|c|c|c|}
\hline Source & DF & Anova SS & Mean Square & F Value & Pr $>$ F \\
\hline x1 & 17 & 3034.250000 & 178.485294 & 21.69 & $<.0001$ \\
\hline x3 & 1 & 633.361111 & 633.361111 & 76.97 & $<.0001$ \\
\hline
\end{tabular}

4.C Fisher's least-significant difference test (pairwise $t$ tests): comparisons significant at the 0.05 level are indicated by ${ }^{\star * *}$.

\begin{tabular}{|c|c|c|c|c|}
\hline \multicolumn{5}{|c|}{ Comparisons significant at the 0.05 level are indicated by ${ }^{* * *}$. } \\
\hline x3 Comparison & Difference Between Means & $\begin{array}{l}\text { Simul } \\
\text { Confic }\end{array}$ & $\begin{array}{l}\text { ous } 95 \% \\
\text { e Limits }\end{array}$ & \\
\hline $\mathrm{R}-\mathrm{C}$ & 8.3889 & 6.3716 & 10.4062 & $* * *$ \\
\hline
\end{tabular}

comparisons and polynomial models.

The TNM for 18 lots changed from 1,000 to 39,000 . The TNM values of the controlled samples ranged from 1,000 to 23,000 and from 1,000 to 39,000 for the salt-reduced samples. The reduced-salt samples had an approximately 3-times higher TNM than the control samples. The exception was sample taken from lot L11, where it was assumed that the TNM was very low in comparison to the other samples. The salt content changed in the case of salt-reduced samples from 1.43 to 1.65 and from 2.09 to 2.50 in the case of controlled samples. The morning humidity during the implementation of the study was from $72 \%$ up to $88 \%$. It should also be noted that the relative humidity was higher in the case of samples with higher TNMs. The most often day of the week of the production of the sausages was Wednesday (5 times). Table 2 presents the study variables: types, ranges or their scale points, units if there are any. Figure 2 displays the described experimental set-up. Figure 2 shows the difference in the TNMs between the control and the salt-reduced samples for all lots on the $40^{\text {th }}$ day.

Testing for normality (see Table 3 ) did not confirm the normal distribution for sets A (30 samples and 15 lots) and B (36 samples and 18 lots); therefore, the non-parametric analysis of variance was used. The results of the analysis of variance are displayed in Table 4. The model (Table 4.A) represented the relation between dependent TNM $\left(\operatorname{Rlog}_{10} \mathrm{Y}\right)$, which was first ranked, and two independent variables lot (X1) and salt concentration (X3). These results indicated that the overall model is statistically significant, $\mathrm{F}=24.76$, $\mathrm{p}$-values was less than 0.0001 , and accounted for a significant portion of the variables X1 and X3. The R-squared was 0.96326 , and indicated that model accounted for $96 \%$ of the variations of X1 and X3. The variables X1 and X3 (Table 4.B) are also statistically significant ( $\mathrm{p}$-values were less than 0.0001 ). 
4.D Fisher's least-significant difference test (pairwise $t$ tests): comparisons significant at the $\mathbf{0 . 0 5}$ level are indicated by ${ }^{* * *}$.

\begin{tabular}{|c|c|}
\hline x1 Comparison & \\
\hline $\begin{array}{l}\text { L17 - L9, L3, L5, L1, L12, L13, L4, L8, L14, L7, L10, } \\
\text { L11 }\end{array}$ & $* * *$ \\
\hline L6- L3, L5, L1, L12, L13, L4, L8, L14,L7, L10,L11 & $* * *$ \\
\hline L16 - L3, L5, L1, L12, L13, L4, L8, L14, L7, L10, L11 & $* * *$ \\
\hline L18 - L5, L1, L12, L13,L4,L8,L14,L7,L10,L11 & $* * *$ \\
\hline L15 - L5, L1, L12, L13,L4,L8,L14,L7,L10,L11 & $* * *$ \\
\hline L2- L12, L13, L4, L8, L14, L7, L10, L11 & $* * *$ \\
\hline L9- L17, L14, L7, L10, L11 & $* * *$ \\
\hline L3- L17, L6, L16, L11 & $* * *$ \\
\hline L5- L17, L6, L16, L18, L15, L11 & $* * *$ \\
\hline L1- L17, L6, L16, L18, L15 & $* * *$ \\
\hline L12 - L17, L6, L16, L18, L15, L2 & $* * *$ \\
\hline L13 - L17, L6, L16, L18, L15, L2 & $* * *$ \\
\hline L4- L17, L6, L16, L18, L15, L2 & $* * *$ \\
\hline L8- L17, L6, L16, L18, L15,L2 & $* * *$ \\
\hline L14 - L17, L6, L16, L18, L15, L2, L9 & $* * *$ \\
\hline L7- L17, L6, L16, L18, L15, L2, L9 & $x \neq *$ \\
\hline L10 - L17, L6, L16, L18, L15, L2, L9 & $\overline{x *}$ \\
\hline L11 - L17, L6, L16, L18, L15, L2, L9, L3, L5 & $t * * *$ \\
\hline
\end{tabular}

Comparison of the rank means between the salt-reduced (R) and control (C) samples showed significant difference at the 0.05 (Table 4.C).

Comparisons of the rank means between lots showed significant ones at the 0.05 and they are listed in Table 4.D. Depending on the significant comparisons, the lots could be classified into three groups. In the first group, the lots had TNM less than 10,000. The first group lots were L5, L1, L12, L13, L4, L8, L14, L7, L10, and L11. In the second group, the lots had, TNM less than or equal to 10,000 , and less than 20,000. There were lots L2, L9 and L3. In the third group, had a TNM equal to or greater than 20,000. The third group lots were L6, L15, L16, L17, L18. The classifications of the lots are shown in Figure 2 using the two bold black horizontal lines. Each member of the first group was significantly different from each of the third group of lots and vice versa. L2, L9 and L3 were, with regard to their means, not significantly different to particular members of the first or to the third group and therefore were classified into second group. Such significant differences between the lots based on the TNM were not expected. This was the main reason that the humidity $(\mathrm{x} 4)$ was included in the calculations. It was important variable, which influenced on TNM.

Nonparametric Kruskal-Wallis tests (Table 4.E) indicated the same as nonparametric ANOVA, i.e., that there were the significant differences between the lots (X1) ( $\mathrm{p}$-value $=0.0462)$ and the salt-reduced and control samples
Non-parametric tests

4.E Non-parametric tests

\begin{tabular}{|l|r|r|r|}
\hline Test & Variable & Chi-Square & Pr $>$ Chi-Square \\
\hline Kruskal-Wallis & X1 & 27.8920 & 0.0462 \\
\hline Kruskal-Wallis & X3 & 5.8221 & 0.0158 \\
\hline
\end{tabular}

$\mathrm{X} 3$ ( $\mathrm{p}$-value $=0.0158)$.

Findings for sets A on the basis of models A.A. and A.B and for set B on the basis of models B.A and B.B (Table 7):

The intercept was statistically not significant in models A.A and B.A. The correlation coefficient was much higher in the model A.B and B.B without the intercept, the RMS values were approximately $20 \%$. The explanation was that the majority of the lots had a low TNM at the beginning, but still not zero (see Figure 2).

TNM $\left(\log _{10} \mathrm{Y}\right)$ was inversely proportional to the salt content (X3).

The relation between TNM $\left(\log _{10} \mathrm{Y}\right)$ and lot $(\mathrm{X} 1)$ : X1 was not statistically significant for the models A.A, A.B and B.A, but it was significant in model B.B. Figure 2 shows that lots L16, L17 and L18 had higher TNMs in comparison to the other lots and set B had these lots included. Therefore X1 became statistically significant.

TNM $\left(\log _{10} Y\right)$ was proportional with the relative humidity $\mathrm{X} 4(\%)$ and it was statistically significant. In the future the relative humidity should be permanently controlled during the production of meat products.

The relation between TNM $\left(\log _{10} Y\right)$ and the day in the week (X5) was not statistically significant .

The models A.A, A.B, B.A and B.B were used for prediction of TNM for lots L16, L17 and L18, but calculated TNM values were too low. The models were too general for prediction, but they determined relationships between selected variables.

The results of the second part of the study, set C, D: determination of variables influencing on TNM on the basis of comparison of groups, expressing the variability of the TNM.

The data for set $\mathrm{C}$ were normally distributed (see Table 3) for $\log _{10} Y$ (the $p$ value for Kolmogorov-Smirnov test was $0.15)$.

For lots L16, L17 and L18, the TNMs were never bellow 1,000 on the first day after production. The average TNM was 1,833 on the first day for the $2.37 \%$ salt concentration and 4,100 for the $1.61 \%$ concentration. The relative humidity during the production days of lots L16, L17 and L18 was quite high, i.e., over $80 \%$.

Figure 3 shows the TNMs of the samples on days 1, 5, 10, $15,20,25,30,35$, and 40 . The higher TNMs are for the saltreduced samples (dashed lines), and the lower TNMs for the control samples (solid lines). On average, the significant change was between the $30^{\text {th }}$ and $35^{\text {th }}$ day, after which it was slowly increasing, decreasing or staying the same: 3 samples out of 6 had a lower TNM, 1 had the same TNM, and 2 samples had a higher TNM than on the $35^{\text {th }}$ day. In the case of the previously mentioned samples of lot L11 the number of microorganisms drastically decreased before the $40^{\text {th }}$ day after the production. The TNMs on the $20^{\text {th }}$ and $25^{\text {th }}$ days after the production for lot L16 were greater in comparison 


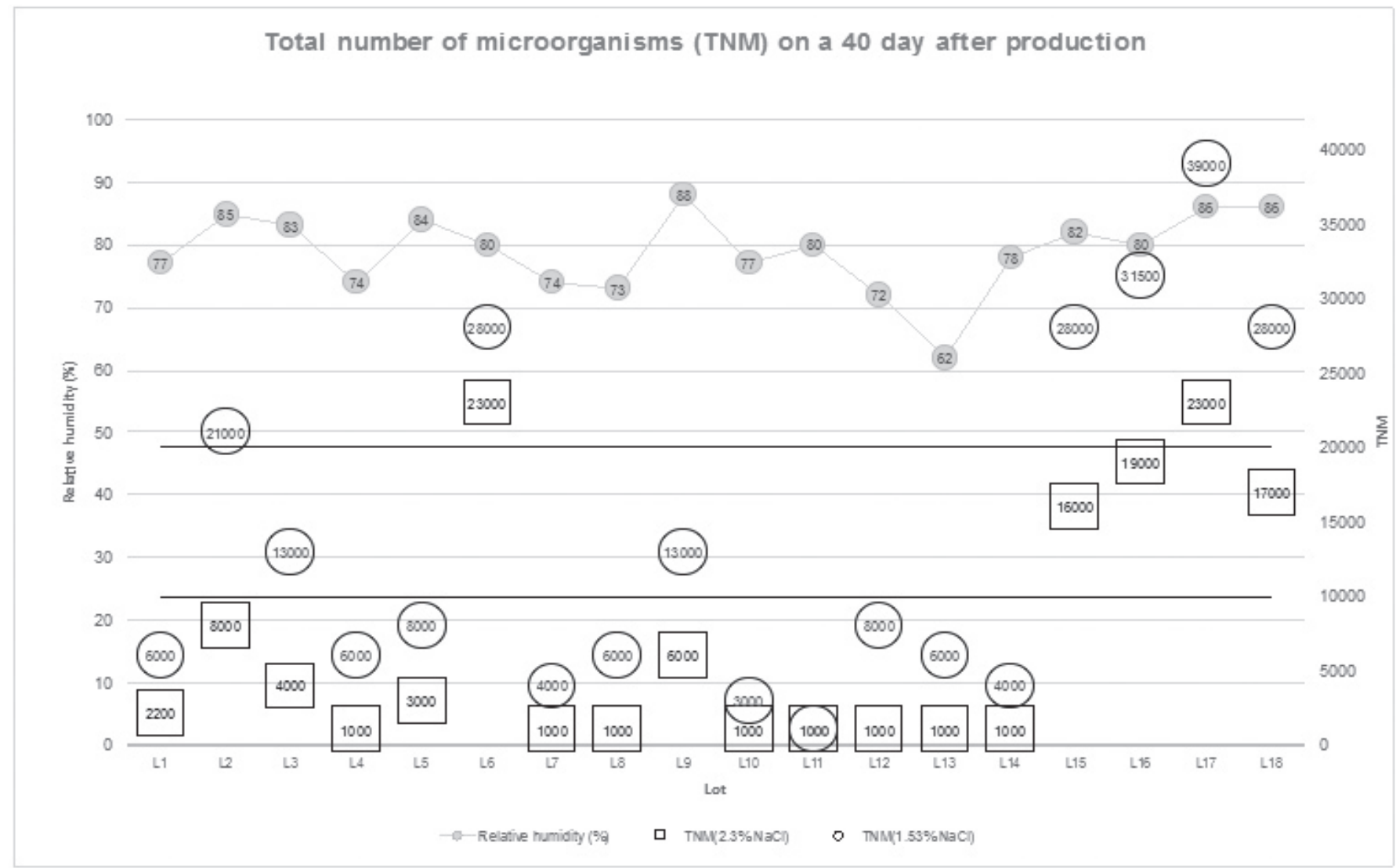

Fig. 2: Total number of microorganisms (TNMs) on the $40^{\text {th }}$ day after production for 18 lots with relative humidity in $\%$ on the day of the production (numbers at the top of the dashed horizontal lines) for the control samples with average salinity $2.32 \%$ (circles with TNM values) and the salt-reduced samples with average salinity $1.55 \%$ (squares with TNM values).

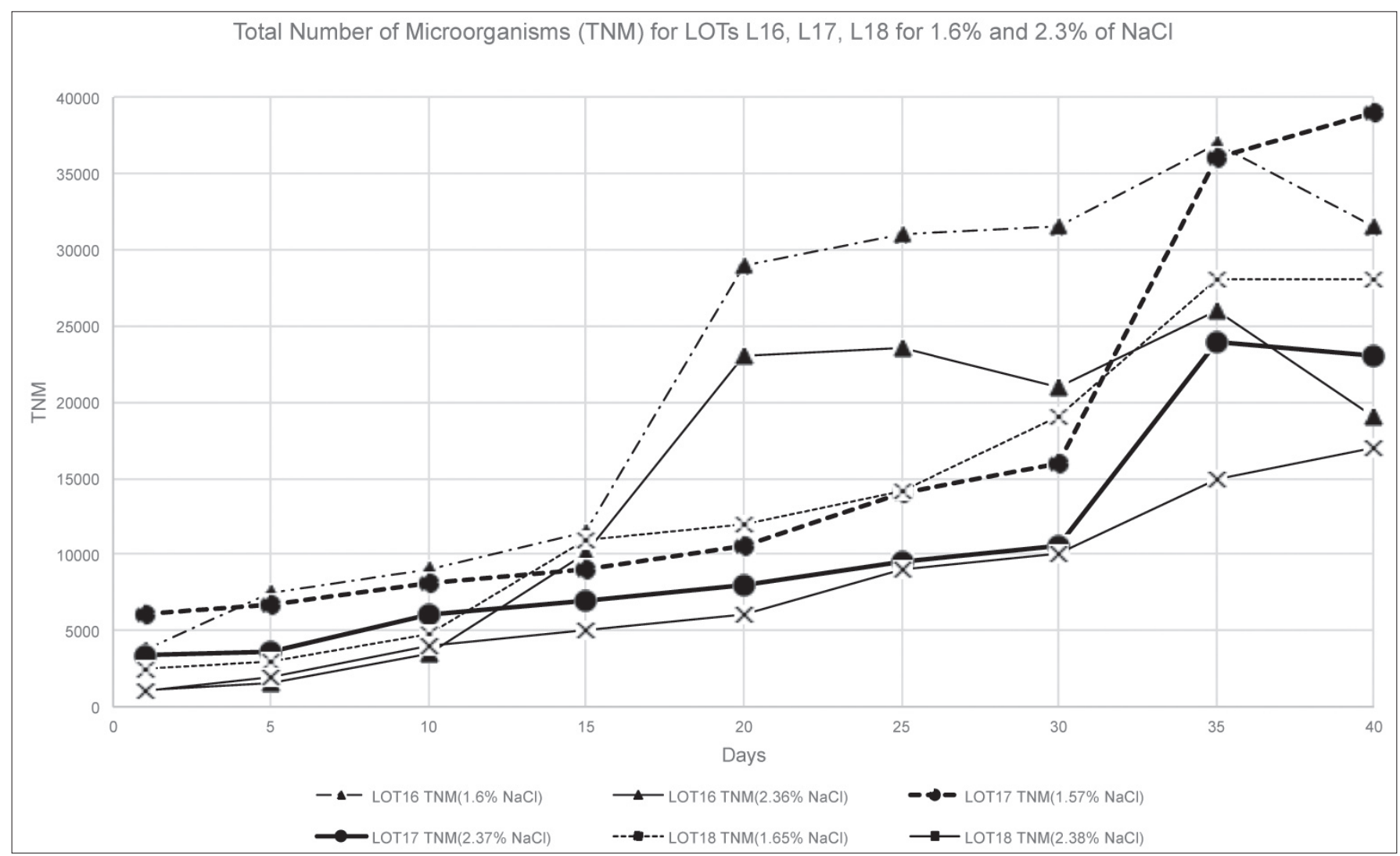

Fig. 3: Total number of microorganisms (TNMs) for lots L16 (lines with triangles), L17 (lines with circles) and L18 (lines with squares) on the $1^{\text {st }}, 5^{\text {th }}, 10^{\text {th }}, 15^{\text {th }}, 20^{\text {th }}, 25^{\text {th }}, 30^{\text {th }}, 35^{\text {th }}$ and $40^{\text {th }}$ day after the production. The solid lines present the TNMs for the control samples. The dashed lines present the TNMs for the salt-reduced samples. 
Table 5: The analysis of variance for Set $\mathrm{C}$ is presented.

5.A Model

\begin{tabular}{|l|r|r|r|r|r|}
\hline Source & DF & Sum of Squares & Mean Square & F Value & Pr $>$ F \\
\hline Model & 12 & 7.93937633 & 0.66161469 & 40.34 & $<.0001$ \\
\hline Error & 41 & 0.67236900 & 0.01639924 & & \\
\hline Corrected Total & 53 & 8.61174533 & & & \\
\hline
\end{tabular}

\begin{tabular}{|r|r|r|r|}
\hline R-Square & Coeff Var & Root MSE & $\log$ Y Mean \\
\hline 0.921924 & 3.207547 & 0.128060 & 3.992444 \\
\hline
\end{tabular}

5.B Significance of the variables in the model

\begin{tabular}{|l|r|r|r|r|r|}
\hline Source & DF & Anova SS & Mean Square & F Value & Pr $>$ F \\
\hline x1 & 2 & 0.41303633 & 0.20651817 & 12.59 & $<.0001$ \\
\hline x2 & 8 & 6.55682700 & 0.81960338 & 49.98 & $<.0001$ \\
\hline x3 & 1 & 0.74483267 & 0.74483267 & 45.42 & $<.0001$ \\
\hline x4 & 1 & 0.22468033 & 0.22468033 & 13.70 & 0.0006 \\
\hline
\end{tabular}

5.C Fisher's least-significant difference test (pairwise t tests): comparisons significant at the 0.05 level are indicated by ${ }^{\star * \star}$.

\begin{tabular}{|c|rr|r|r|r|}
\hline \multicolumn{2}{|c|}{ Comparisons significant at the 0.05 level are indicated by ${ }^{* * *}$. } \\
\hline $\begin{array}{c}\text { x1 } \\
\text { Comparison }\end{array}$ & \multicolumn{2}{|c|}{ Difference Between Means } & \multicolumn{3}{|c|}{ Simultaneous 95\% Confidence Limits } \\
\hline L16-L17 & & 0.06450 & -0.03930 & 0.16830 \\
\hline L16-L18 & 0.20917 & 0.10537 & 0.31296 & $* * *$ \\
\hline L17-L18 & 0.14467 & 0.04087 & 0.24846 & $* * *$ \\
\hline
\end{tabular}

5.D Fisher's least-significant difference test (pairwise $t$ tests): comparisons significant at the 0.05 level are indicated by ${ }^{\star * *}$.

\begin{tabular}{|c|r|r|r|r|}
\hline & \multicolumn{4}{|c|}{ Comparisons significant at the 0.05 level are indicated by ${ }^{* * *}$. } \\
\hline $\begin{array}{c}\text { x3 } \\
\text { Comparison }\end{array}$ & \multicolumn{2}{|c|}{ Difference Between Means } & \multicolumn{2}{|c|}{ Simultaneous 95\% Confidence Limits } \\
\hline R - C & 0.23489 & 0.16450 & 0.30527 & $* * *$ \\
\hline
\end{tabular}

5.E Fisher's least-significant difference test (pairwise $t$ tests): comparisons significant at the 0.05 level are indicated by ${ }^{* * *}$.

\begin{tabular}{|c|r|r|r|r|}
\hline \multicolumn{4}{|c|}{ Comparisons significant at the 0.05 level are indicated by ${ }^{* * *}$. } \\
\hline $\begin{array}{c}\mathrm{x} 4 \\
\text { Comparison }\end{array}$ & Difference Between Means & \multicolumn{2}{|c|}{ Simultaneous 95\% Confidence Limits } & \\
\hline H1 - H2 & 0.13683 & 0.06218 & 0.21149 & $* * *$ \\
\hline
\end{tabular}

$\mathrm{H} 1=80 \%$ humidity, $\mathrm{H} 2=86 \%$ humidity

to lots L17 and L18.

\section{Findings for Set C}

The results of the analysis of variance are presented in Table 5. The model (Table 5.A) represented the relation between dependent TNM $\left(\log _{10} \mathrm{Y}\right)$ and the four independent variables lot (X1), the sampling day (X2), the salt concentration (X3) and humidity (X4). These results indicated that the overall model was statistically significant, $\mathrm{F}=40.34$, p-values were less than 0.0001, and accounted for a significant proportion of variables X1 - X4. The R-squared was 0.921924 and indicated that the model accounted for $92 \%$ of the variations of $\mathrm{X} 1$ X4. The variables X1 - X4 (Table 5.B) were also statistically 
Table 6: Spearman rank-order and Pearson product-moment correlations, the p-value under the null hypothesis of zero correlations for the pairs of analysis variables, one independent variable $\mathrm{X}_{\mathrm{i}}$ and the dependent variable $\mathrm{Y}$, are displayed for sets $\mathrm{A}, \mathrm{B}, \mathrm{C}$, and $\mathrm{D}$.

\begin{tabular}{|l|l|r|r|l|}
\hline Set & Variables & $\mathrm{r}$ & Prob $>|\mathrm{r}|$ & Correlation \\
\hline A & X3 & -0.32 & 0.0846 & Pearson \\
\hline (30 samples) & X4 & 0.39 & 0.0333 & Pearson \\
\hline & X1 & -0.16 & 0.3942 & Spearman \\
\hline & X5 & 0.17 & 0.3567 & Spearman \\
\hline
\end{tabular}

\begin{tabular}{|l|l|r|r|l|}
\hline B & X3 & -0.26 & 0.1222 & Pearson \\
\hline (36 samples) & X4 & 0.49 & 0.0024 & Pearson \\
\hline & X1 & 0.27 & 0.1061 & Spearman \\
\hline & X5 & 0.22 & 0.1960 & Spearman \\
\hline
\end{tabular}

\begin{tabular}{|l|l|r|r|l|}
\hline C & X3 & -0.29 & 0.0293 & Pearson \\
\hline (55 samples) & X4 & -0.25 & 0.0684 & Pearson \\
\hline & X1 & -0.24 & 0.0806 & Spearman \\
\hline & X2 & 0.86 & 0.0001 & Spearman \\
\hline & X5 & -0.24 & 0.0806 & Spearman \\
\hline
\end{tabular}

\begin{tabular}{|l|l|r|r|l|}
\hline D & X3 & -0.26 & 0.0158 & Pearson \\
\hline (85 samples) & X4 & 0.21 & 0.0598 & Pearson \\
\hline & X1 & 0.21 & 0.0552 & Spearman \\
\hline & X2 & 0.10 & 0.3449 & Spearman \\
\hline & X5 & 0.03 & 0.7770 & Spearman \\
\hline
\end{tabular}

significant ( $\mathrm{p}$-values were less than 0.0001 for $\mathrm{X} 1, \mathrm{X} 2, \mathrm{X} 3$ and less than 0.0006 for $\mathrm{X} 4$ ). A comparison of the means between the lots showed significant difference at the 0.05 (Table 5.C) between L16 and L18 and between L17 and L18, but not between L16 and L17. Comparison of the means between the salt-reduced (R) and the control (C) samples showed significance at the 0.05 (Table 5.D). A comparison of the means between the morning humidity on the day of the production ( $\mathrm{H} 1=80 \%$ humidity, $\mathrm{H} 2=86 \%$ humidity) also showed a significant difference at the 0.05 (Table 5.D).

During the shelf-life the sausages were kept under the controlled conditions. One repetition of counting TNM was done for lot L16, the salt-reduced sample and for sampling on $30^{\text {th }}$ day after production. The TNM of the first one was 31,000 and for the second one it was 10,500. The mean value was 20,800 and the standard deviation was $+/-14,849$. The coefficient of variation $(\mathrm{CV})$ was $70 \%$. CV was extremely high, but $\mathrm{CV}$ often shows misleading values. Therefore, the intra $\mathrm{CV}$ was calculated to describe a variability within a population of sausages during the shelf-life in the lots L16, L17, and L18.The calculated intraCV was $36.78 \%$ for the set $\mathrm{C}$ (including the repetition).The intra CV for the saltreduced samples in set $\mathrm{C}$ was $35.66 \%$ and for the control salt samples it was $43.24 \%$. The control salt samples had higher variability than the salt-reduced samples. The values showed high variability. The reason was that TNM did not depend only on the salt concentration but on the humidity, lot, some uncontrolled contaminations, micro-flora of a particular sausage during the shelf life and some other reasons. In this case Figure 3 shows the variability of TNMs in the sausages during the shelf-life when the sausages were cooled to $6^{\circ} \mathrm{C}$. Nevertheless, to the intra $\mathrm{CV}$, the analysis of variance showed the significant differences between the salt-reduced and control sausages according to the TNM and the salt concentrations, lots and morning humidity (Table 5).

Pearson and Spearman correlations between variables were calculated. They are presented in Table 6. The correlation between the humidity (X4) and TNM $\left(\log _{10} \mathrm{Y}\right)$ were significant, with a p-value of less than 0.03 (set A) and 0.00 (set B). This indicated strong, positive relationship between these two variables. The relationship was on the limit in the case of set D, p-value was 0.0598 . Set C showed the oposite correlation between $\mathrm{X} 4$ and $\mathrm{Y}$. In the case of set $\mathrm{C}$ only two values of humidity appeared, $80 \%$ and $86 \%$, which is not enough for a determination of the correlations. A significant p-value was also between salt concentration (X3) and TNM $\left(\log _{10} \mathrm{Y}\right)$ for set $\mathrm{C}$ and $\mathrm{D}$. For set $\mathrm{A}$ it was near the limit (p-value was 0.0846 ) and for set B it was not significant.The relationship between days of shelf-life (X2) and TNM $\left(\log _{10} \mathrm{Y}\right)$ was significant only in set $\mathrm{C}$, where the $\mathrm{p}$-value was 0.0001 . The relationship between the day of the production (X5) and TNM $\left(\log _{10} \mathrm{Y}\right)$ was not significant for all sets. 
Table 7: Models' results for A.A, A.B, B.A, B.B, D.A and D.B showing independent variables affecting the dependent variable TNM. The logarithmic values of TNM $\left(\log _{10} \mathrm{Y}\right)$ were taken into the calculations. The variance inflation factor (VIF) and condition index (C.I.) are showing that there is no collinearity between variables. The complex transformations of the independent variables were used for a calculation of models A.C, B.C and D.C with the purpose to decrease RMS(\%) and increase the correlation coefficient values just to confirm the relationship between selected independent variables and the dependent variable and their importance on the basis of their statistical significance.

\begin{tabular}{|c|c|c|c|c|c|c|c|c|}
\hline Set & Model & F value & $\begin{array}{l}\mathrm{p} \text { value } \\
\text { Prob > F }\end{array}$ & Error & $\begin{array}{c}\text { Correlation } \\
\text { coefficient }\end{array}$ & $\begin{array}{l}\text { RMS } \\
(\%)\end{array}$ & $\begin{array}{l}\text { Shapiro- } \\
\text { Wilk }^{*} \\
\text { p Value }\end{array}$ & $\begin{array}{l}\text { Kolmogorov- } \\
\text { Smirnov* } \\
\text { p Value }\end{array}$ \\
\hline A & A.A & 6.36 & 0.0011 & 3.56129 & 0.4250 & 21.65 & 0.7605 & $>0.1500$ \\
\hline A & A.B & 659.58 & $<.0001$ & 3.91450 & 0.9887 & 22.70 & 0.9381 & $>0.1500$ \\
\hline A & A.C & 6.20 & 0.0155 & 1.53837 & 0.8048 & 14.23 & 0.7104 & $>0.1500$ \\
\hline B & B.A & 9.75 & $<.0001$ & 4.56247 & 0.4999 & 22.37 & 0.7977 & $>0.1500$ \\
\hline B & B.B & 876.27 & $<.0001$ & 4.68143 & 0.9898 & 22.66 & 0.9197 & $>0.1500$ \\
\hline B & B.C & 11.72 & 0.0003 & 1.56702 & 0.8884 & 13.11 & 0.6948 & $>0.1500$ \\
\hline $\mathrm{D}$ & D.A & 19.72 & $<.0001$ & 8.20458 & 0.5270 & 19.53 & 0.1614 & $>0.1500$ \\
\hline $\mathrm{D}$ & D.C & 6.64 & $<.0001$ & 6.51144 & 0.7928 & 17.40 & 0.4287 & $>0.1500$ \\
\hline
\end{tabular}

*Tests for normality of residuals

\begin{tabular}{|c|c|c|c|c|}
\hline \multicolumn{4}{|l|}{ Model A.A } \\
\hline \multicolumn{4}{|l|}{ Parameter Estimates } \\
\hline Variable & $\begin{array}{c}\text { Parameter } \\
\text { Estimate }\end{array}$ & $\begin{array}{c}\mathrm{p} \text { value } \\
\text { Prob }>|\mathrm{t}|\end{array}$ & VIF & C.I. \\
\hline Intercept & 3.90588 & 0.1279 & 0 & 1 \\
\hline X1 & -0.00949 & 0.3086 & 1.21 & 6.12 \\
\hline X3 & -0.58188 & 0.0028 & 1.01 & 12.82 \\
\hline X4 & 0.03394 & 0.0074 & 1.11 & 30.78 \\
\hline X5 & 0.09629 & 0.0572 & 1.10 & 100.37 \\
\hline
\end{tabular}

\begin{tabular}{|c|c|c|c|c|}
\hline \multicolumn{4}{|l|}{ Model A.B } \\
\hline \multicolumn{4}{|l|}{ Parameter Estimates } \\
\hline Variable & $\begin{array}{c}\text { Parameter } \\
\text { Estimate }\end{array}$ & $\begin{array}{c}\text { p value } \\
\text { Prob }>|t|\end{array}$ & VIF & C.I. \\
\hline X1 & 0.00383 & 0.2864 & 127.22 & 1 \\
\hline X3 & -0.54865 & 0.0050 & 24.49 & 5.57 \\
\hline X4 & 0.04512 & $<.0001$ & 109.45 & 12.15 \\
\hline X5 & 0.08151 & 0.1062 & 6.96 & 29.18 \\
\hline
\end{tabular}

\begin{tabular}{|l|r|r|r|r|}
\hline \multicolumn{4}{|l|}{ Model B.A } \\
\hline \multicolumn{4}{|l|}{ Parameter Estimates } \\
\hline Variable & $\begin{array}{c}\text { Parameter } \\
\text { Estimate }\end{array}$ & $\begin{array}{c}\text { p value } \\
\text { Prob }>|t|\end{array}$ & \multicolumn{1}{l|}{ VIF } & \multicolumn{1}{l|}{ C.I. } \\
\hline Intercept & -1.03484 & 0.3756 & 0 & 1 \\
\hline X1 & 0.00941 & 0.0308 & 1.11 & 6.59 \\
\hline X3 & -0.52914 & 0.0029 & 1.01 & 12.98 \\
\hline X4 & 0.04303 & 0.0003 & 1.04 & 33.11 \\
\hline X5 & 0.06037 & 0.2044 & 1.07 & 48.61 \\
\hline
\end{tabular}

\begin{tabular}{|l|r|r|r|r|}
\hline \multicolumn{4}{|l|}{ Model B.B } \\
\hline \multicolumn{4}{|l|}{ Parameter Estimates } \\
\hline Variable & $\begin{array}{c}\text { Parameter } \\
\text { Estimate }\end{array}$ & $\begin{array}{c}\text { p value } \\
\text { Prob }>|\mathrm{t}|\end{array}$ & VIF & C.I. \\
\hline X1 & 0.00693 & 0.0324 & 128.86 & 1 \\
\hline X3 & -0.55775 & 0.0014 & 24.38 & 6.01 \\
\hline X4 & 0.03792 & 0.0001 & 118.58 & 12.25 \\
\hline X5 & 0.06231 & 0.1885 & 7.97 & 29.89 \\
\hline
\end{tabular}

\begin{tabular}{|l|r|r|r|r|}
\hline \multicolumn{5}{|l|}{ Model D.A } \\
\hline Parameter Estimates \\
\hline Variable & $\begin{array}{c}\text { Parameter } \\
\text { Estimate }\end{array}$ & $\begin{array}{c}\text { p value } \\
\text { Prob }>|\mathrm{t}|\end{array}$ & \multicolumn{1}{l|}{ VIF } & \multicolumn{1}{l|}{ C.I. } \\
\hline Intercept & -2.53089 & 0.0026 & 0 & 1 \\
\hline X1 & 0.01635 & $<.0001$ & 2.03 & 5.31 \\
\hline X2 & 0.02367 & $<.0001$ & 1.77 & 9.53 \\
\hline X3 & -0.40268 & $<.0001$ & 1.01 & 14.68 \\
\hline X4 & 0.03098 & 0.0002 & 1.39 & 50.73 \\
\hline X5 & -0.02814 & 0.3950 & 1.13 & 66.87 \\
\hline
\end{tabular}

Set $C$ in general did not show the same correlations as sets $\mathrm{A}, \mathrm{B}$ and $\mathrm{D}$; therefore, the linear regression was not calculated. The calculated correlation coefficients justified the use of the linear regression for the sets $\mathrm{A}, \mathrm{B}$ and $\mathrm{D}$ to determine the relationships between variables on the basis of the models in more detail.

Table 7 shows the parameters of the calculated linear polynoms. RMS (\%) values were in all cases approximately $20 \%$; nevertheless, the models were highly significant ( $p$ values Prob $>$ F were lower than 0.05). A decimal logarithmic transformation of the dependent variable was used. By using 
Table 8: The results of parametric and non-parametric comparison tests of sensory analysis including the colour of the section and the exterior colour, the odour and the taste on the $40^{\text {th }}$ day from three evaluators for the lots 11264 , 11265 and 11266 are presented. ColourR, OdourR, and TasteR means the salt-reduced samples. ColourC, OdourC, and TasteC means the control samples.

\begin{tabular}{|c|c|c|c|c|c|c|}
\hline & $\begin{array}{l}\text { ColourR- } \\
\text { ColourC }\end{array}$ & $\begin{array}{l}\text { ColourR- } \\
\text { ColourC }\end{array}$ & $\begin{array}{l}\text { OdourR- } \\
\text { OdourC }\end{array}$ & $\begin{array}{l}\text { OdourR- } \\
\text { OdourC }\end{array}$ & TasteR-TasteC & $\begin{array}{l}\text { TasteR- } \\
\text { TasteC }\end{array}$ \\
\hline $\begin{array}{c}\text { Normality test for } \\
\text { differences }\end{array}$ & Statistic W & $\begin{array}{l}\text { P Value } \\
\operatorname{Pr}<W\end{array}$ & Statistic W & $\begin{array}{l}\text { P Value } \\
\operatorname{Pr}<W\end{array}$ & Statistic W & $\begin{array}{l}\text { P Value } \\
\operatorname{Pr}<W\end{array}$ \\
\hline Shapiro-Wilk & 0.833482 & 0.0489 & 0.85671 & 0.0883 & 0.751938 & 0.0057 \\
\hline Parametric test & $\mathrm{T}$ value & $\begin{array}{l}\mathrm{p} \text { Value } \\
\operatorname{Pr}>|\mathrm{t}|\end{array}$ & $\mathrm{T}$ value & $\begin{array}{l}\mathrm{p} \text { Value } \\
\operatorname{Pr}>|\mathrm{t}|\end{array}$ & $\mathrm{T}$ value & $\begin{array}{l}\mathrm{p} \text { Value } \\
\operatorname{Pr}>|\mathrm{t}|\end{array}$ \\
\hline Paired t-test & -4.24 & 0.0028 & -0.60 & 0.5632 & -3.77 & 0.0054 \\
\hline Non-parametric test & Statistic S & $\begin{array}{l}\text { P Value } \\
\operatorname{Pr}>=|S|\end{array}$ & Statistic S & $\begin{array}{l}\text { P Value } \\
\operatorname{Pr}>=|S|\end{array}$ & Statistic S & $\begin{array}{l}\text { P Value } \\
\operatorname{Pr}>=|S|\end{array}$ \\
\hline $\begin{array}{l}\text { Wilcoxon Signed-Rank test } \\
\text { (Paired test) }\end{array}$ & -14 & 0.0156 & -4 & 0.6875 & -19.5 & 0.0234 \\
\hline Parametric test & t Value & $\operatorname{Pr}>|t|$ & t Value & $\operatorname{Pr}>|t|$ & t Value & $\operatorname{Pr}>|t|$ \\
\hline $\begin{array}{c}\text { Two independent samples } \\
\text { t-test }\end{array}$ & 4.02 & 0.0010 & 0.71 & 0.4867 & 2.05 & 0.0570 \\
\hline Non-parametric test & $\mathrm{Z}$ & $\begin{array}{c}\text { Two-Sided } \\
\operatorname{Pr}>|\mathrm{Z}|\end{array}$ & $\mathrm{Z}$ & $\begin{array}{l}\text { Two-Sided } \\
\operatorname{Pr}>|\mathrm{Z}|\end{array}$ & $\mathrm{Z}$ & $\begin{array}{c}\text { Two-Sided } \\
\operatorname{Pr}>|\mathrm{Z}|\end{array}$ \\
\hline $\begin{array}{c}\text { Wilcoxon-Mann-Whitney } \\
\text { test (two independent } \\
\text { samples) }\end{array}$ & -2.8815 & 0.0040 & -0.7867 & 0.4314 & -1.6784 & 0.0933 \\
\hline
\end{tabular}

additional transformations of the independent variables (spline polynoms) the RMS decreased to $14.23 \%$ (A.C) $13.11 \%$ (B.C).

The normality tests (Shapiro-Wilk, Kolmogorov-Smirnov) of the distributions of residuals for models were not significant; the distributions of residuals were not significantly different from a normal distribution.

The multi-collinearity diagnostic parameters, the variance inflation factor (VIF) and the condition index (C.I.), for each term in the model were calculated. If VIFs exceed 10 and C.I. 100 , than the multicollinearity could be indicated. The C.I. values were smaller than 100 and therefore we could conclude that the diagnostic parameters did not show the existence of multi-collinearity.

\section{Findings for Set $\mathrm{D}$ on the basis of linear regression}

Set D had 84 samples and one repetition. We confirmed all the already-determined correlations. Statistically significant were $\mathrm{X} 1, \mathrm{X} 2, \mathrm{X} 3$ and $\mathrm{X} 4$, and had a strong influence on TNM.

The result of the third part of the study: significance of the influence of salt reducing on taste, odour and colour of the sausages

Table 8 shows the sensory evaluation of the Kranjska sausages from lots L16, L17 and L18 on the $40^{\text {th }}$ day after production. The normality test confirmed the normal distribution of differences for odour $(\mathrm{p}=0.0883)$. The $\mathrm{p}$ value for the colour was on the limit $(p=0.0489)$ and for taste, a normal distribution was not confirmed. Q-Q plots were not exceptionally non-normal; even the Shapiro-Wilk test assumes a normal distribution only for difference OdourROdourC. Because the number of samples was rather small we calculated all test for all differences.

The difference between the colours (colour of the section and the external colour) of the two products with a different salt content was statistically confirmed. All tests gave $p$ value smaller then 0.05. All tests confirmed no difference between the samples for the odour. In all cases $\mathrm{p}$ value was higher then 0.05 . This meant that a reduced salt content did not affect the odour of the sausage. The paired tests confirmed the difference in taste between the salt-reduced and control sausages and the independent tests not. The paired t-test is usually not sensitive to deviations from normality, i.e., these deviations must be really abnormal; this was not the case in our study. There were no abnormal deviations. But because the evaluators gave higher ranks to sausages with higher salt concentration, it is obvious that the paired tests were more realistic. The p-value was 0.0054 for the paired t-test and 0.0234 for the Wilcoxon signed-rank test. 


\section{CONCLUSIONS}

The conclusion of the study was that salt is an important preservative that affects the microbiological stability of the Kranjska sausage and a sensory analysis. All the lots of the sausages with a reduced salt content had an increased content of TNMs.

The important variables during the production of the sausages, besides the salt concentration, were the relative humidity and the lot. The relative humidity should in future be permanently monitored during production. The lot was representing the microbiological status of the meat particles at the beginning of the production for the sausages. The origin of the meat particles was monitored and it will be also in the future, because the suppliers or the microbiological status of the meat particles could be changed.

The variability of TNM during the shelf-life was expressed with the intra CV and was lower for the salt-reduced sausages and higher for the control salt concentration. It was obvious that TNM did not depend only on the salt concentration, but also on some other variables, for example, humidity and lot. There was also the possibility of the development of the microflora inside the sausages during the shell-life showing higher TNMs, but in this case more samples have to be analysed and the type of microorganisms should be determined.

The developed polynomial models determined and confirmed the correlations and strong influences between TNM and the variables salt concentration, lots and humidity. Polynomial models were too general and not precise enough to be also used for the prediction, but they were useful for a determination of the relations between variables, i.e., TNM was increasing with humidity and decreasing with higher salt concentration.

The sensory assessment showed that the salt reduction had no statistically significant effect on the odour of the sausage. However, there was a statistically significant impact on the colour and the flavour of the sausages.

According to the results of our study, we demonstrated that salt is a preservative that plays an important role in the production of sausages; it has an impact on both the flavour and the colour of the product and on the microbiological stability and shelf-life.

\section{ACKNOWLEDGEMENT}

The samples of Kranjska sausage were produced by Košaki d.o.o. Slovenia. The authors are very thankful to the company and its personnel for their cooperation and performing this study. The authors thank Dr Marjan Tušar for his critical reading of the manuscript.

\section{REFERENCES}

1. Aaslyng MA, Vestergaard C, Koch AG. The effect of salt reduction on sensory quality and microbial growth in hotdog sausages, bacon, ham and salami. Meat Sci. 2014;96:47-55.
2. BOX GEP, Cox DR. An analysis of transformations. J.R.Stat. Soc. Series B.Stat. Methodol. 1964;26(2):211-252.

3. Cohen J. Statistical Power Analysis for the Behavioral Sciences. Lawrence Erlbaum Associates, New Jersey, USA, 1988.

4. Commission Regulation (EC) No. 2073/2005 on microbiological criteria for foodstuffs 2005. http://eur-lex.europa.eu/legal-content/en/ALL/?uri=CELEX:32005R2073 (15.11.2005).

5. Desmond E. Reducing salt: A challenge for the meat industry. MeatSci. 2006;74:188-196.

6. Desmond E. Reducing salt in meat and poultry products. In: Kilcast D, Angus F (eds.), Reducing salt in foods. Woodhead Publishing Limited, Cambridge, England, 2007:233-55.

7. Doyle ED, Glass HA. Sodium Reduction and Its Effect on Food Safety, Food Quality, and Human Health. Compr. Rev. FoodSci. FoodSaf. 2010;9:44-56.

8. Freund RJ, Littell RC. System for regression. SAS Institute Inc., Cary, NC, USA, 1991.

9. Giaouris E, Heir E, Hébraund M, Chorianopoulos N, Langsrud S, Møretrø T, Habimana O, Desvaux M, Renier S, Nychas GJ. Attachment and biofilm formation by foodborne bacteria in meat processing environments: causes, implications, role of bacterial interactions and control by alternative novel methods. Meat Sci. 2014;97:298-309.

10. Hwang CA. Development of predictive models to enhance microbiological safety of ready-to-eat meats. J. Nutr. Food Sci. 2013;3(4)70.

11. Hwang CA, Porto-Fett ACS, Juneja VK, Ingham SC, Ingham $\mathrm{BH}$, Luchansky JB. Modeling the survival of Escherichia coli O157:H7, Listeria monocytogenes, and Salmonella Typhimurium during fermentation, drying, and storage of soudjouk-style fermented sausage. Int. J. Food Microbiol. 2009;129:244-252.

12. ISO 1841-2:1996. International Organisation for Standardization (ISO), Determination of chloride content - Part 2: Potentiometric method, Meat and Meat Products, Geneva, 1996.

13. ISO 4833:2003E. International Organisation for Standardization (ISO), Microbiology of food and animal feeding stuffs - Horizontal method for the enumeration of microorganisms - Colony-count technique at 30 degrees C, Food Microbiology, Geneva, 2003.

14. Kilcast D, den Ridder C. Sensory issues in reducing salt in food products. In: Kilcast D, Angus F (eds.), Reducing salt in foods. Woodhead Publishing Limited, Cambridge, England, 2007: 201-220.

15. Kloss L, Dawn Meyer J, Graeve L, Vetter W. Sodium intake and its reduction by food reformulation in the European Union - A review. NFS Journal 2015;1:9-19.

16. Kropf IL. Effects of lowering (percentage of) salt in meat products on the content of the number of microorganisms (Vpliv zniževanja soli $\mathrm{v}$ mesnih izdelkih na vsebnost skupnega števila mikroorganizmov) [master thesis]. Maribor. Faculty for Agriculture and Life Sciences, University of Maribor, 2012.

17. Mejlholm O, Gunvig A, Borggaard C, Blom-Hanssen J, Mellefont L, Ross T, Leroi F, Else T, Visser D, Dalgaard P. 
Predicting growth rates and growth boundary of Listeria monocytogenes - An international validation study with focus on processed and ready-to-eat meat and seafood. Int. J. Food Microbiol. 2010;141(3):137-150.

18. Ministry of Health, Government of the Republic of Slovenia. National Action Plan to reduce salt intake in the diet of people in Slovenia for the period 2010-2020 (Nacionalni akcijski načrt za zmanjševanje uživanja soli v prehrani prebivalcev Slovenije za obdobje 20102020). 2010. www.dlib.si/stream/URN:NBN:SI:DOCZF4CAGWN/.../PDF (3.10.2011).

19. Montgomery DC, PeckEA. Multicollinearity in regression. In: Wadsworth HM (eds.), Handbook of statistical methods for engineers and scientists. McGraw-Hill publishing company, New York, USA, 1990:15.3-15.23.

20. Pereira AGT, Ramos EM, Teixeira JT, Cardoso GP, Ramos ALS, Fontes PG. Effects of the addition of mechanically deboned poultry meat and collagen fibers on quality characteristics of frankfurter-type sausages. Meat Sci. 2011;89:519-525.

21. Puolanne E, Halonen M. Theoretical aspects of waterholding in meat. Meat Sci. 2010;86(1):151-161.

22. Institute of public health of the Republic of Slovenia in the cooperation with the Slovene Consumers' association. Guidelines for microbiological safety, which are intended for the final consumer (Smernice za mikrobiološko varnost živil, ki so namenjena končnemu potrošniku). Authors:Rupel T, Pavlica T, Planina P, Vidrih J, Retelj M, Car T, Gošnjak M, Lušicky $M$, Bošnjak D, Pretnar $G$, Sabotin D., 2009.

23. Sharedeh D, Gatellier P, Astruc T, Daudin JD. Effects of $\mathrm{pH}$ and $\mathrm{NaCl}$ levels in a beef marinade on physicochemical states of lipids and proteins and on tissue microstructure. Meat Sci. 2015;110:24-31.

24. Slovenian Environment Agency. Whether information for Maribor in year 2011.http://www.arso.gov.si/ .

25. Soladoye OP, Juárez ML, Aalhus JL, Shand P, Estévez M. Protein Oxidation in Processed Meat: Mechanisms and Potential Implications on Human Health. Compr. Rev. Food Sci. Food Saf. 2015;14:106-122.

26. SAS 9.4 (TS1M1) for Windows. SAS Institute Inc., Cary, NC, USA, 2002-2012.

27. SAS/STAT ${ }^{\oplus} 9.2$ User's Guide. SAS Institute Inc., Cary, NC, USA, 2008.

28. World Health Organization(WHO). Diet, nutrition and the prevention of chronic diseases. Report of a Joint WHO/FAO Expert Consultation, Who Technical Report Series, Geneva, 2002. http://whqlibdoc.who.int/trs/who_ TRS_916.PDF (28.1.-1.2.2002).

29. Winsberg S, Ramsay JO. Monotonic transformations to additivity using splines. Biometrika1980;67(3):669-674. 


\section{Vpliv zniževanja soli na vsebnost skupnega število mikroorganizmov in senzorično analizo v kranjskih klobasah v času njihovega roka uporabnosti}

\section{IZVLEČEK}

Sol je pomembna sestavina v proizvodnji mesnih izdelkov in vsako zniževanje vsebnosti soli zahteva posebno obravnavo. Ta študija je bila izvedena z namenom ugotavljanja vpliva zmanjševanja soli na rast mikroorganizmov v kranjskih klobasah in na senzorično oceno v času njihovega roka trajanja. 18 lotov klobas je bilo pripravljenih z zmanjšano količino (1,6\%) in z kontrolno količino (2,3\%) soli neposredno na proizvodni liniji. Analiziranih je bilo 85 klobas. Podatki so bili uporabljeni za primerjave skupin (ANOVA) in za odkrivanje značilnih spremenljivk (polinomski modeli), ki vplivajo na skupno število mikroorganizmov (SŠM). Signifikantne razlike so bile določene med loti Kranjskih klobas (ki predstavljajo mikrobiološko stanje nadeva), med vzorci klobas z zmanjšano količino in kontrolno količino soli in med različnimi stopnjami zračne vlage. Korelacije in signifikantna razmerja so bila določena med SŠMs in loti, koncentracijo soli v klobasi in relativno vlažnostjo. Polinomi so bili preveč splošni, da bi se lahko uporabljali za napovedovanje. Senzorična analiza je bila izvedena na 40. dan. Ocenili smo 18 klobas. Pri ocenjevanju je zmanjšanje soli prineslo klobasam nižje ocene. Manj slane klobase so vsebovale več mikroorganizmov.

Ključne besede: Kranjska klobasa, zmanjševanje soli, senzorično ocenjevanje, modeli, relativna vlažnost 